\title{
Immunohistochemical detection of dopamine D2 receptors in human pituitary adenomas
}

\author{
Marek Pawlikowski
}

Department of Neuroendocrinology, Medical University of Lodz, Poland

\begin{abstract}
Thirty one pituitary adenomas and 3 samples of peritumoral anterior pituitary tissue were immunostained with an antibody raised against dopamine D2 receptor protein. The positive reactions were found in cell cytoplasm, a subpopulation of cell nuclei and the intratumoral blood vessels walls. As expected, the positive immunostaining was shown in cytoplasm and/or cell nuclei of all examined prolactinomas (7/7). In acromegaly the positive D2 staining occurred in 5/7 samples, in gonadotropinomas in $6 / 8$ and in plurihormonal adenomas $2 / 4$. The lowest expression was observed in corticotropinomas (1/5). These findings corroborate with the well known efficacy of D2 agonists in the treatment of prolactinomas and somatotropinomas, and support the rationale of the therapeutic trials with these compounds in gonadotropinomas. Moreover, the presence of D2 receptors in intratumoral blood vessels walls constitutes the possibility of the anti-angiogenic action of D2 agonists in pituitary adenomas.
\end{abstract}

Key words: dopamine, D2 receptors, pituitary adenomas, immunohistochemistry, angiogenesis

\section{Introduction}

Dopamine (DA) is well know to effect directly the anterior pituitary gland. It has been known for many decades that DA plays a role as the main hypothalamic inhibiting factor of prolactin secretion [1,2]. In 1978 Pawlikowski et al. [3] showed that DA directly inhibits the pituitary growth The dopamine receptors, which are responsible for the direct effects of DA at the anterior pituitary level, were characterized as belonging to D2 type [for review see 4]. A synthesis of bromocriptine, a first selective and long-lasting agonist of D2 receptors, allowed to introduce this drug to the medical treatment of pituitary adenomas, particularly prolactinomas [5]. Nowadays bromocriptine and other newer D2 agonists consist a first line treatment for prolactinomas [6]. Dopamine agonists were also applied in the treatment of acromegaly, because of the paradoxical action of DA on growth hormone secretion in acromegalic patients [7]. However, their effects are poorer in comparison to the longacting somatostatin analogs like octreotide and lanreotide. Clinical trials suggest that DA receptors agonists are also effective in the treatment of the non-

Correspondence: M. Pawlikowski, Dept. of Neuroendocrinology, Medical University of Lodz, 91425 Lodz, Poland;

tel./fax.: (+4842) 6365427,

e-mail: marek.pawlikowski@umed.lodz.pl functioning pituitary adenomas [for review see 8]. Recently, the chimeric molecules acting simultaneously on somatostatin $2 \mathrm{~A}$ and dopamine D2 receptors were developed and their enhanced potency in inhibiting both growth hormone and prolactin secretion was shown [9]. These compounds were also found to suppress in vitro the viability of cells isolated from the clinically nonfunctioning pituitary adenomas and were suggested as potential future medical treatment for this type of malignancies $[8,10]$.

\section{Material and methods}

Tissue samples. Thirty one human pituitary adenomas, surgically excised, were examined. The material included 7 samples of acromegaly, 7 prolactinomas, 8 clinically nonfunctioning adenomas expressing gonadotropins, 4 clinically nonfunctioning plurihormonal adenomas and 5 corticotropinomas (4 manifesting as Cushing's disease and 1 silent corticotropinoma). In the group of plurihormonal adenomas, 2 expressed GH, PRL and LH, 1 GH, FSH and LH, and the remaining $1 \mathrm{GH}$ and LH. Additionally, three samples of the non-tumoral anterior pituitary gland, adjacent to the excised tumors were also examined.

Immunohistochemistry. D2 receptor immunostaining was performed using the rabbit anti-human dopamine receptor D2 polyclonal antibody. This antibody was raised against the 28 amino acid sequence from the human D2 receptor within the cytoplasmic loop 3 and recognizes both long and short form of the human receptor, and its specifity was approved in earlier publications $[11,12]$ The antibody was purchased from Chemicon International (USA Canada). It was applied in working dilution 1:100. 
Each human tumor was also immunostained using the primary polyclonal or monoclonal antibodies against the pituitary hormones and alpha-subunit (alpha-SU).The following primary antibodies against the pituitary hormones were used: anti-prolactin (polyclonal, Dako, Denmark). Anti-growth hormone (polyclonal, Dako), anti-LH (monoclonal, Dako), anti-FSH (monoclonal, Dako) anti-TSH (monoclonal, Immunotech, France) anti-ACTH (polyclonal, Sigma) and anti- alpha-SU (monoclonal, Immunotech, France). The more detailed informations on pituitary hormone immunohistochemistry were published in an earlier paper [13] The hormone immunohistochemistry, taken together with clinical data, served to classification of pituitary adenoma samples (see above). The visualization of primary anti-receptor and anti-hormone antibodies was done using the StreptABComplex/HRP Duet (Dako Cytomation) following the procedure recommended by the manufacturer.. In brief, the biotinylated goat antibody against rabbit and mouse immunoglobulin was applied as the secondary antibody, followed by streptavidin-biotinylated horseradish peroxidase complex and 3,3'-diaminobenzidine as chromogen.

Ethical issues. The study was approved by the Local Bioethical Committee, decision number RNN/191/09/ KE dated September, $22^{\text {th }} 2009$.

\section{Results}

In non-tumoral anterior pituitary tissues as well as in pituitary adenomas, the positive immunostaining with anti-D2 receptor antibody in the investigated tissues appears in two main localizations. The weak to moderate cytoplasmic immunostaining concerns majority, or in other cases, only some groups of cells (Fig. 1 and 2 ). Only in 3 cases of pituitary adenomas the immunostaining of cell membranes was also found (Fig. 3). It concerned 2 samples of prolactinomas and 1 sample of somatotropinoma in acromegalic patient. The moderate to strong immunostaining was also observed in a subpopulation of cell nuclei (Fig. 4) and in the walls of blood vessels (Fig. 5). In the normal peritumoral anterior pituitary tissues, the D2 receptor immunostaining of cell cytoplasm was found in two samples. The immunostaining was weak to moderate and concerned almost all glandular cells. In one sample the cytoplasmic immunoreaction was absent, but nuclear immunostaining was visible in a small subpopulation of nuclei $(<10 \%)$. Moreover, in one sample we could see the D2 immunopositivity in blood vessel walls. In pituitary adenomas, cytoplasmic and/or nuclear D2 immunostaining was detectable in 22 but absent in 8 tumors. The expression seems to be highest in prolactinomas (7/7). In acromegaly the positive D2 staining occurred in $5 / 7$ samples, in gonadotropinomas in 6/8 and in plurihormonal adenomas in $2 / 4$. The lowest expression was observed in corticotropinomas $(1 / 5)$. If we consider only cytoplasmic localization of D2 immunostaining, the following frequences were observed: prolactinomas 6/7, somatotropinomas $4 / 7$, gonadotropinomas $3 / 8$, corticotropinomas $1 / 5$ and plurihormonal adenomas $1 / 4$. The D2- immunopositive intratumoral blood vessels were found in 18 specimens. In three cases, D2immunopositive blood vessels occurred in spite of the absence of immunoreaction in glandular cells. In respect to the hormonal phenotype of the adenomas, the vascular D2 immunopositivity occurs mostly in gonadotropinomas $(6 / 8)$ but is rare in corticotropinomas $(1 / 5)$ and plurihormonal adenomas (1/4).

\section{Discussion}

The data presented above confirm the earlier studies showing that dopamine D2 receptors are detectable in pituitary adenoma cells by immunohistochemistry [1416]. The highest expression of D2 immunopositivity in prolactinomas corroborates with the well known efficacy of dopamine agonists in the treatment of this kind of pituitary tumors. The relatively high expression of $\mathrm{D} 2$ receptors in $\mathrm{GH}$-secreting adenomas in patients suffering from acromegaly is in agreement with the data reported by Ferone et al. [14] and Stefaneanu et al.[16] and are compatible with the partial responsiveness of these tumors to dopamine agonists. The high incidence of D2 immunopositivity was found in clinically nonfunctioning pituitary adenomas diagnosed immunohistochemically as gonadotropinomas (75\%). This result is roughly similar to that reported by Pivonello et al. [17], who have found the expression of D2 receptor mRNA, by means of RT-PCR technique, in approximatively $70 \%$ of clinically nonfunctioning pituitary adenomas. The quoted authors showed also that cabergoline treatment of the patients resulted in $56 \%$ of cases in significant tumor shrinkage, and the effect correlated with the D2 receptor expression, especially that of short isoform. In our earlier study we showed that exposure of cells isolated from clinically nonfunctioning pituitary adenomas (mostly gonadotropinomas) cultured in vitro to bromocriptine or to dopamine-somatostatin chimeric molecule BIM $23 \mathrm{~A} 387$ resulted in $60 \%$ of samples by reduced cell viability [10]. In our material, the expression of D2 receptors in corticotropinomas was rather low $(20 \%)$. It seems to stay in opposition to the observations of Pivonello et al. [15] and Stefaneanu et al. [16] who found D2 receptors expressed in $80 \%$ and $70 \%$ of the investigated corticotroph adenomas, respectively. However, our material of corticotropinomas was small and our estimation of frequency is not conclusive. Besides from the cytoplasmic localization, which was reported also by other authors applying the immunohistochemical method to detect the D2 receptors in pituitary tumors $[14,16]$, we observed also a nuclear immunostaining. This nuclear staining usually was accompanied by cytoplasmic immunopositivity, but sometimes appeared in spite of the immunonegative cytoplasm. The meaning of such nuclear localization, noticed earlier also by Stefaneanu et al. [16], remains 

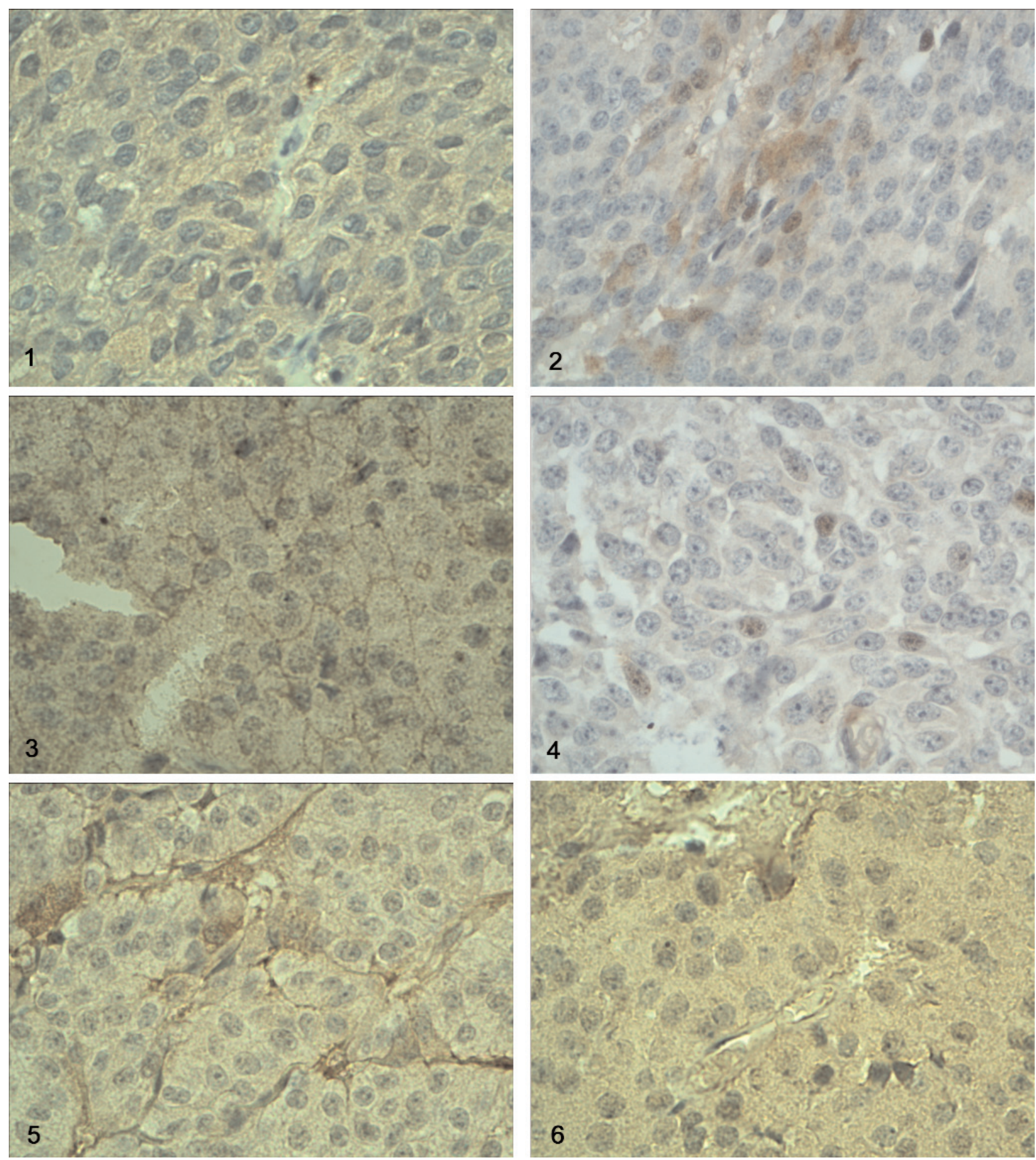

Fig. 1. Moderate cytoplasmic immunostaining with anti-D2 receptor antibody in the prolactinoma (man, 45 years old, original magnification $\times 400$ ). Fig. 2. A cluster of D2-immunopositive cells of prolactinoma (woman, 59 years old, original magnification $\times 400$ ). Fig. 3. Membrane localization of D2 receptor immunostaining in prolactinoma (man, 58 years old, original magnification $\times 400$ ). Fig. 4. D2 immunopositive cell nuclei in corticotropinoma (woman, 29 years old, original magnification $\times 400$ ). Fig. 5. Immunostaining of intratumoral blood vessels walls with anti-D2 receptor antibody in gonadotropinoma (man,46 years old, original magnification $\times 400$ ). Fig. 6. D2 receptor immunostaining of endothelium in the intra-tumoral blood vessel. Gonadotropinoma (woman, 56 years old, original magnification $\times 400$ ).

to be recognized in further studies. Another unexpected localization of D2 immunopositivity concerns the blood vessel walls. This localization seems to corroborate with the recent data demonstrating the role of dopamine and D2 receptors in angiogenesis. Dopamine acting via D2 receptors was shown to suppress the action of vascular endothelial growth factor A on both tumor endothelial and bone-marrow derived 
endothelial progenitor cells [18]. This findings was confirmed by the observation of enhanced angiogenesis and malignant tumor growth in dopamine-depleted or D2 receptor knockout mice [19]. The finding done in the present study, that D2 receptor immunoreactivity are often detectable in vascular walls of pituitary adenomas, suggests that D2-agonists may act, at least in part, via suppression of tumoral angiogenesis. However, because we do not use the blockade of immunoreaction with the excess of antigen protein, we cannot totally exclude the unspecific staining, particularly of the unusual localizations.

Acknowledgements: This study was supported by the Medical University of Lodz. The author is grateful to professor Andrzej Radek, MD, PhD , head of the Clinic of Neurosurgery and Surgery of Peripheral Nerves,, for samples of human pituitary adenomas, and to Professor Jolanta Kunert-Radek, MD, PhD , from the Clinic of Endocrinology, Medical University of Łódź, for the clinical data of patients. The skillful technical assistance of Mrs Maria Jaranowska, Mrs Malgorzta Jędrzejewska and Mrs Anna Opłatowska is greatly appreciated.

\section{References}

[1] Shaar CJ, Clemens JA. The role of catecholamines in the release of anterior pituitary prolactin in vitro. Endocrinology. 1974;95:1202-1212.

[ 2] MacLeod RM, Lehmeyer JE. Studies on the mechanism of the dopamine-mediated inhibition of prolactin secretion. Endocrinology. 1974;94:1077-1085.

[3] Pawlikowski M, Kunert-Radek J, Stepien H. Direct antiproliferative effect of dopamine agonists on the pituitary gland in organ culture. J Endocr. 1978;79:245-246.

[4] Pivonello R, Ferone D, Lombardi G et al. Novel insights in dopamine receptor physiology. Eur J Endocrinol. 2007; 156(supl.1):S13-S21.

[5] Fluckiger E, Wagner HR. 2-Br-alpha ergocryptin beinflussung von fertilitat und lactation bei der ratte. Experientia. 1968;24:1130-1131.

[ 6] Casanueva FF, Molitch ME, Schlechte JA et al. Guidelines of the Pituitary Society for the diagnosis and treatment of prolactinomas. Clin Endocrinol (Oxf). 2006;65:265-273.

[ 7] Benker G, Zah W, Hackenberg K et al. Long -term treatment of acromegaly with bromocryptine: postprandial HGH levels and response to TRH and glucose administration. Horm Metab Res. 1976;8:291-295.

[ 8] Ferone D, Pivonello R, Resmini E et al. Preclinical and clinical experiences with the role of dopamine receptors in the treatment of pituitary adenomas. Eur J Endocrinol. 2007;156 (supl.1):S37-S43.

[ 9] Saveanu A, Lavaque E, Gunz C et al. Demonstration of enhanced potency of a chimeric somatostatin/dopamine molecule BIM 23A387, in suppressing growth hormone and prolactin secretion from human pituitary somatotroph adenoma cells. J Clin Endocrinol Metab. 2002;87:5545-5552.

[10] Gruszka A, Kunert-Radek J, Radek A et al. The effect of selective sst1,sst2,sst5 somatostatin receptor agonists, a somatostatin/dopamine (SST/DA) chimera and bromocriptine on "clinically non-functioning" pituitary adenomas in vitro. Life Sci. 2006;78:689-693.

[11] Wang H. Dopamine D2 receptors are present in prefrontal cortical afferents and their targets in patches of the rat caudate - putamen nucleus. J Comparative Neurology. 2002;442:392404.

[12] Mengual E, Pickel V. Ultrastructural immunocytochemical localization of the dopamine D2 receptor and tyrosine hydroxylase in the rat ventral pallidum. Synapse. 2002;43: 151-162.

[13] Pawlikowski M, Gruszka A, Kurnatowska I et al. Proliferating cell nuclear antigen (PCNA) expression in pituitary adenomas: relationship to the endocrine phenotype of adenoma. Folia Histochem Cytobiol. 2006;44:37-41.

[14] Ferone D, de Herder W, Pivonello R et al. Correlation of in vitro and in vivo somatostropic adenoma responsiveness to somatostatin analogs and dopamine agonists with immunohistochemical evaluation of somatostatin and dopamine receptors and electron microscopy. J Clin Endocr Metab. 2008;93:1412-1417.

[15] Pivonello R. Ferone D, de Herder WW et al. Dopamine receptor expression and function in corticotroph pituitary tumors. $J$ Clin Endocr Metab. 2004;89:2452-2462.

[16] Stefaneanu L, Kovacs K, Horvath E et al. Dopamine D2 receptor gene expression in human adenohypophysial adenomas. Endocrine. 2001;14:329-330.

[17] Pivonello R, Matrone C, Filipella M et al. Dopamine receptor expression and function in clinically nonfunctioning pituitary tumors: comparison with the effectiveness of cabergoline treatment. J Clin Endocr Metab. 2004;89:1647-1648.

[18] Chakroborty D, Sarkar C, Basu B, Dasgupta PS, Basu S. Catecholamines regulate tumor angiogenesis. Cancer Res. 2009; 69:3727-3730.

[19] Basu S, Sarkar C, Chakroborty D et al. Ablation of peripheral dopaminegic nerves stimulates malignant tumor growth by inducing vascular permeability factor/vascular endothelial growth factor - mediated angiogenesis. Cancer Res. 2004; 64:5551-5555.

Submitted: 9 November, 2009 Accepted after reviews: 22 April, 2010 